удК 342.9

DOI https://doi.org/10.32837/apdp.v0i85.1878

Є. О. Яковенко, В. С. Смирнова

\title{
ЗОВНІШНЬОЕКОНОМІЧНА ТОРГІВЕЛЬНА ПОЛІТИКА УКРАЇНИ ПІД ЧАС ЗАПРОВАДЖЕННЯ КАРАНТИННИХ ОБМЕЖЕНЬ
}

Постановка проблеми. Регулювання зовнішньої торгівлі та захист внутрішнього ринку є складниками державної митної політики України. Запровадження режиму карантину, бувши необхідним запобіжним заходом запобігання поширенню гострої респіраторної хвороби COVID-19, вплинуло на всі сфери життєдіяльності людей та негативно відобразилось на зовнішньоекономічній торгівельній політиці України.

Аналіз останніх досліджень i публікацій. Дослідженню особливостей застосування митних режимів України присвячено праці таких видатних вітчизняних науковців: О.П. Гребельника, Н.В. Осадчої, Б.А. Кормич, М.Г. Шульги, О.М. Дем'янюка, М.В. Мельника, Т.В. Тучака та інших. Вагомий науковий внесок у розвиток зовнішньоторговельної політики України на європейських і світових ринках мають праці таких науковців: О.Б. Мниха, С.М. Макухи, О.В. Зірко. Ураховуючи, що проблеми, досліджені в поданій роботі хоч і виникли зовсім нещодавно, проте вже завдали чималих утрат економіці України, тема є актуальною та потребує подальшого дослідження.

Метою статті є розробка заходів, спрямованих на стабілізацію зовнішньоекономічної торгівельної політики України після виходу з карантинного режиму. Для досягнення поставленої мети у статті вирішуються такі завдання: досліджується зовнішньоекономічна торгівельна політика України; проводиться аналіз митних режимів України, зокрема сучасний стан імпорту та експорту в режимі карантинних обмежень.

Виклад основного матеріалу дослідження. Зовнішньоекономічна торгівельна політика держави є цілеспрямованою діяльністю щодо здійснення внутрішньої і зовнішньої політики держави, шляхом застосування механізмів державного управління, які спрямовані на ефективне співробітництво в системі світового господарства з дотриманням національних економічних інтересів і безпеки громадян, передбачає послідовність, економічну самостійність і державний суверенітет України та гарантує динамічний розвиток економіки і зростання добробуту народу [1, с. 125]. Державна митна політика є складником державної економічної політики, бувши системою принципів та напрямів діяльності держави у сфері захисту митних інтересів та забезпечення митної безпеки України, регулювання зовнішньої торгівлі, захисту внутрішнього ринку, розвитку економіки України та їі інтеграції до світової економіки [2].

Вагоме місце в задоволенні фінансових інтересів держави та сприянні зовнішньоекономічній діяльності відіграють митні режими [3, с. 54]. За визначенням, даним О.П. Гребельником, митний режим - це «встановлена (залежно від характеру та мети переміщення предмета через митний кордон України) сукупність по- 
ложень або митних процедур, яка застосовується до цих предметів. Ця сукупність положень визначає правовий статус товару та транспортних засобів, що переміщуються через митну територію держави або по ній задля митного оформлення» [4, с. 322]. Відповідно до митного кодексу митний режим є комплексом взаємопов'язаних правових норм, котрі, відповідно до заявленої мети переміщення товарів через митний кордон України, визначають митну процедуру щодо цих товарів, ïx правовий статус, умови оподаткування й зумовлюють їх використання після митного оформлення [5, п. 25, ч. 1 ст. 4]. Законодавець виділяє чотирнадцять митних режимів:

1) імпорт (випуск для вільного обігу);

2) реімпорт;

3) експорт (остаточне вивезення);

4) реекспорт;

5) транзит;

6) тимчасове ввезення;

7) тимчасове вивезення;

8) митний склад;

9) вільна митна зона;

10) безмитна торгівля;

11) переробка на митній території;

12) переробка за межами митної території;

13) знищення або руйнування;

14) відмова на користь держави [5, ст. 70].

Важливу роль у здійсненні зовнішньоекономічної діяльності для України відіграють саме режими імпорту та експорту. Імпорт (випуск для вільного обігу) $є$ митним режимом, відповідно до якого іноземні товари після сплати всіх митних платежів, установлених законами України на імпорт цих товарів, та виконання всіх необхідних митних формальностей випускаються для вільного обігу на митній території України [5, ст. 74]. Експорт (остаточне вивезення) є митним режимом, відповідно до якого українські товари випускаються для вільного обігу за межами митної території України без зобов'язань щодо їх зворотного ввезення [5, ст. 82].

За даними інфографіки Міністерства розвитку економіки, торгівлі та сільського господарства України, за підсумками 2 місяців(січня-лютого) 2020 року імпорт товарів щодо 2 місяців 2019 року скоротився на 265,1 млн дол. (3,0\%). Серед регіонів України найбільший негативний внесок у динаміку імпорту товарів за 2 місяці 2020 року спостерігався в місті Києві (-1,9\%), Дніпропетровській області (-1,1\%), Донецькій області (-1,0\%), Запорізькій області (-0,9\%), Закарпатській області $(-0,5 \%)$,Миколаївській області (-0,3\%), Рівненській області (-0,2\%), Луганській області (-0,2\%), Вінницькій області (-0,2\%), також скорочення імпорту товарів продемонстрували Чернівецька, Чернігівська та Черкаська області. Водночас за 2 місяці 2020 року 13 областей додали позитивного внеску у формування показника імпорту товарів. Найбільшого позитивного внеску до приросту імпорту товарів додала Одеська область $(+1,7)$, суттєвого позитивного внеску до приросту імпорту також додали: Львівська область $(+1,2)$, Київська область $(+1,1 \%)$. 
До найбільших країн-партнерів в імпорті товарів до України належать: Європейський Союз (42,1\%), Китай (15,7\%), Російська Федерація $(9,5 \%)$, США (6\%), Білорусь $(5,4 \%)$, Туреччина $(4,4 \%)$, Японія $(1,8 \%)$, Індія $(1,7 \%)$, Швейцарія $(1,5 \%)$ та інші [6, с. 1]. Хоча у 2020 році імпорт товарів з Російської Федерації до України скоротився, проте він і досі займає передові позиції серед країн-партнерів в імпорті товарів, ігноруючи продовження на 1 рік (до 31 грудня 2020 року) терміну дії постанови Кабінету Міністрів України від 30 грудня 2015 р. № 1147 [7], як захід у відповідь на продовження РФ недружніх дій щодо України (рішень Уряду РФ від 18.04.2019 щодо розширення переліку заборонених до ввезення в РФ товарів, заборони вивезення з РФ в Україну нафти та деяких видів нафтопродуктів, установлення з 01.06.2019 вивезення вугілля, палива та газу з РФ в Україну виключно на підставі дозволів, які видаватимуться Міністерством економічного розвитку РФ; а також продовження до 31 грудня 2020 року заборони ввезення в РФ сільгосппродукції походженням з України) [8].

Із 12 березня 2020 року впроваджено карантинний режим, відповідно до статті 29 Закону України «Про захист населення від інфекційних хвороб» [9, ст. 29] та пп. 8 п.2 Постанови Кабінету міністрів України «Про запобігання поширенню на території України гострої респіраторної хвороби COVID-19, спричиненої коронавірусом SARS-CoV-2» [10, пп. 8 п. 2], агропродовольчі ринки були заборонені до 11 травня 2020 року.

Закриття державних кордонів, тривала відсутність доступу вітчизняних виробників до продовольчих ринків, а отже, й відсутність збуту продукції спровокувала появу численних економічних проблем аграріїв. Оскільки надлишки продукції псуються, відсутні місця для їх зберігання, зростає рівень безробіття. Водночас більша частина продовольчих товарів, імпортуючись з інших країн, потрапляє до прилавків супермаркетів, які на період карантину є основним місцем збуту.

Підтримуючи іноземних виробників та здійснюючи зовнішньоекономічну торговельну політику, Україна втрачає якісний внутрішній ринок, до того ж маючи проблеми на зовнішньому ринку. Наприклад, картоплю в Україну офіційно постачає здебільшого Білорусь, але значна її частина має російське походження. Купуючи в Росії картоплю у фермерів по 15 центів США за кг, в Україні її продають по 3035 центів [11].

На сьогодні Україна збільшила імпорт яблук і скоротила їх експорт: «Високі внутрішні ціни на яблуко в Україні в поточному сезоні стимулюють їх імпорт. Основний обсяг яблук для свіжого ринку ввозиться з Польщі, хоча на ринок уже почали надходити й перші партії яблука преміальної якості з Італії, продаються у високому ціновому сегменті. Звичайно, що в такій ситуації дуже складно експортувати яблука, оскільки і Польща, і навіть Молдова були більш конкурентними за ціною на яблука, ніж Україна», - зазначив економіст інвестиційного департаменту Продовольчої й сільськогосподарської організації ООН (FA0)» Андрій Ярмак [12]. До того ж один із великих експортерів яблук зазначив, що він має великі проблеми із продажами. Оскільки Італія, Норвегія, Іспанія, Кувейт і ще кілька важливих для експорту яблук країн перестали приймати вантажі, тож частина товару «зависла» в портах. Також деякі з опитаних виробників плодоовочевої продукції зазначили, 
що вже протягом декількох тижнів не можуть завезти в Україну куплені в ЄС саджанці та добрива. І це може стати проблемою для багатьох компаній у найближчі тижні, адже сезон польових робіт розпочався, а більшість засобів захисту рослин постачають в Україну саме з тих країн ЄС, де найбільші проблеми з коронавірусом: Італії, Іспанії, Франції, Німеччини та Нідерландів [13]. І навіть молочна продукція імпортується в Україну з Свропейського Союзу [14].

Ситуація є непередбачуваною з багатьох причин. Серед найбільших ризиків $\epsilon$ нестабільність курсу гривні й неможливість передбачити його перспективи, глобальна економічна криза, котра може різко знизити попит на продукцію, зокрема й плодоовочеву, й подальше розповсюдження коронавірусу в ЄС та Україні. Ураховуючи невизначеність, українські садівники та овочівники просто діють відповідно до обставин і наразі не розробляють жодних антикризових планів. Представники ж гуртового сегменту торгівлі, які не мають власного виробництва, визнали, що зважають на варіант тимчасового припинення бізнес-діяльності, якщо торгівля суттєво ускладниться, адже нині ризики є занадто великими [14].

Маючи чорноземні родючі землі, Україна купує товари в закордонних виробників, аргументуючи нерентабельністю ціни вітчизняного продукту. До того ж, ураховуючи, що якість є основою формування ціни (не беремо зараз у розрахунок ПДВ тощо), виходить, що українські товари є більш якісними за іноземні. За прогнозами Голови МВФ, вихід із кризового стану світової економіки становитиме не менше трьох років, оскільки економічне падіння спостерігається у 170 країнах. До пропозицій виходу із кризового стану належать такі: «витрачати стільки, скільки зможемо, а потім витрачати трохи більше на лікарів, медсестер та вразливе населення» - зазначила Кристаліна Георгієва [15].

Висновки. Складна та тривала ситуація в Україні, котра склалась унаслідок введених державою карантинних заходів, на зовнішніх та внутрішніх ринках засвідчила, що одним із шляхів її вирішення на внутрішньому продовольчому ринку є закупівля якісних продовольчих товарів державою у вітчизняних виробників. Надавши їм такі преференції, на час карантину держава по-справжньому підтримає вітчизняних виробників на внутрішньому продовольчому ринку, отримає від цього тільки позитивний зиск, зокрема у вигляді не скорочення робочих місць, стабільності у виплаті заробітних плат, надходження податкових платежів до бюджетів різних рівнів. До перспективного плану виходу із кризового стану держава може ініціювати розробку та запровадження на час карантину програм із підтримки вітчизняних виробників на внутрішньому продовольчому ринку.

\section{Jimepamypa}

1. Борисенко О.М. Сутність зовнішньоекономічної політики та ії вплив на розвиток національного господарства. Вісник Національної акаделії державного управління. Серія: державне управління. Вип. № 1. 2011. С. 120-126. Режим доступу: http://visnyk.academy.gov.ua/wp-content/ uploads/2013/11/2011-1-17.pdf (дата звернення 16.05.2020p.). С. 125.

2. Митна політика. Сайт Міністерства фінансів Украӥни. Режим доступу: https://mof.gov.ua/ uk/customs-policy (дата звернення 16.05.2020p.).

3. Тучак Т.В., Могильська М.О. Особливості застосування митних режимів України в умовах інтеграції до ЄС. Світове господарство і міжнародні економічні відносини. Східна Європа: економіка, 
бізнес та управління. Вип. № 6(17). 2018. С. 52-55. Режим доступу:http://www.easterneurope-ebm. in.ua/journal/17_2018/11.pdf (дата звернення 16.05.2020р.).

4. Гребельник О.П. Митна справа: підручник. 5-те вид. оновл. та доповн. Київ : Центр учбової літератури, 2017. 400 с. С. 322.

5. Митний кодекс України від 13.03.2012 p. № 4495-VI (у ред. від 02.04.2020). П. 25, ч. 1. Ст. 4. Електронний ресурс. Режим доступу: https://zakon.rada.gov.ua/laws/show/4495-17(дата звернення 16.05.2020 p.).

6. Інфографіка щодо загальних підсумків імпорту товарів України за 2 місяці 2020 року. Сайт Міністерства розвитку економіки, торгівлі та сільського господарства Украӥни. C. 1. Режим доступу: https://www.me.gov.ua/Documents/List?lang=uk-UA\&id=7e82c6e6-e65b-44ae8a9a-48b6851f6d47\&tag=Infografika-import- (дата звернення 16.05 .2020 р.).

7. Про заборону ввезення на митну територію України товарів, що походять із Російської Федерації: Постанова Кабінету Міністрів України від 30.12.2015 р. № 1147 (у ред. від 12.11.2019). Режим доступу: https://zakon.rada.gov.ua/laws/show/1147-2015-\% D0\% BF (дата звернення 16.05.2020p.).

8. Про внесення змін до постанови Кабінету Міністрів України від 30.12.2015 р. № 1147: Постанова Кабінету Міністрів України від 05.07.2019 p. № 605. Режим доступу: https://www.kmu.gov.ua/ npas/pro-vnesennya-zmin-do-postanovi-kabinetu-ministriv-ukrayini-vid-30-grudnya-2015-r1147-s-605-050719 (дата звернення 16.05.2020 p.).

9. Про захист населення від інфекційних хвороб: Закон України від 06.04.2000р. № 1645-III (у ред. від 18.04.2020). Ст. 29. Режим доступу: https://zakon.rada.gov.ua/laws/show/1645-14\#n241 (дата звернення 16.05 .2020 р.).

10. Про запобігання поширенню на території України гострої респіраторної хвороби COVID-19, спричиненої коронавірусом SARS-CoV-2: Постанова Кабінету Міністрів України від 11.03.2020 p. № 211 (у ред. від 11.05.2020). Режим доступу: https://zakon.rada.gov.ua/laws/show/211-2020$\%$ D0\% ВF (дата звернення 16.05 .2020 р.).

11. Україна продовжуе імпортувати рекордні обсяги картоплі з Pociі. Caŭm Zaxid.net. Режим доступу: https://zaxid.net/ukrayina_prodovzhuye_importuvati_rekordni_obsyagi_kartopli_z_rosiyi_ n1496924 (дата звернення 16.05 .2020 р.).

12. Україна різко збільшила імпорт яблук і скоротила їх експорт. Zaxid.net. Режим доступу: https://zaxid.net/ukrayina_rizko_zbilshila_import_yabluk_i_skorotila_yih_eksport_n1497868 (дата звернення 16.05 .2020 р.).

13. Експорт фруктів та овочів з України впав через пандемію коронавірусу.Zaxid.net. Режим доступy: https://zaxid.net/eksport_fruktiv_ta_ovochiv_z_ukrayini_vpav_cherez_pandemiyu_koronavirusu_ n1499212 (дата звернення 16.05 .2020 р.).

14. Експорт фруктів та овочів з України впав через пандемію коронавірусу. Zaxid.net. Режим доступy: https://zaxid.net/eksport_fruktiv_ta_ovochiv_z_ukrayini_vpav_cherez_pandemiyu_koronavirusu_ n1499212 (дата звернення 16.05 .2020 р.).

15. Глава МВФ розповіла, скільки років знадобиться на відновлення світової економіки після пандемії COVID-19. Сайm - УНIAH. Режим доступу: https://www.unian.ua/economics/finance/glavamvf-rozpovila-skilki-rokiv-znadobitsya-na-vidnovlennya-svitovoji-ekonomiki-pislya-pandemiji-covid-19novini-ukrajina-10999397.html (дата звернення 16.05 .2020 p.).

\section{Анотація}

Яковенко С. О., Смирнова В. С. Зовнішньоекономічна торгівельна політика України під час запровадження карантинних обмежень. - Стаття.

Досліджена зовнішньоекономічна торгівельна політика України; проведений аналіз митних режимів України, зокрема сучасний стан імпорту та експорту в режимі карантинних обмежень. Зовнішньоекономічна торгівельна політика держави є цілеспрямованою діяльністю щодо здійснення внутрішньої і зовнішньої політики держави шляхом застосування механізмів державного управління, які спрямовані на ефективне співробітництво в системі світового господарства з дотриманням національних економічних інтересів і безпеки громадян. Державна митна політика є системою принципів та напрямів діяльності держави у сфері захисту митних інтересів та забезпечення митної безпеки України, регулювання зовнішньої торгівлі, захисту внутрішнього ринку, розвитку економіки України та іï інтеграції до світової економіки. У роботі описано митні режими та здійснено поглиблений аналіз режимів: імпорту та експорту. Досліджено статистичні показники імпорту та експорту за січень-лю- 
тий 2020 року та проведено їх зіставлення з показниками попереднього року, внаслідок чого виявлено скорочення імпорту товарів на 265,1 млн дол. $(3,0 \%)$. Проведено аналіз динаміки імпорту товарів серед регіонів України, встановлено, що найбільший негативний внесок у динаміку імпорту товарів за 2 місяці 2020 року спостерігається в місті Києві (-1,9\%). Установлено, що до найбільших країн-партнерів в імпорті товарів до України належать: Європейський Союз $(42,1 \%)$, Китай $(15,7 \%)$, Російська Федерація (9,5\%), США (6\%), Білорусь (5,4\%), Туреччина $(4,4 \%)$, Японія $(1,8 \%)$, Індія $(1,7 \%)$, Швейцарія $(1,5 \%)$ та інші. Висвітлено вплив упровадження карантинних заходів на економіку України, зокрема закриття агропродовольчих ринків до 11 травня 2020 року. Доведено, що, підтримуючи іноземних виробників та здійснюючи зовнішньоекономічну торговельну політику, Україна втрачає якісний внутрішній ринок, до того ж, маючи проблеми на зовнішньому ринку. Як приклад, у роботі описується імпорт картоплі, яблук та молока. Описується ситуація на внутрішньому та зовнішньому торгівельних ринках України, зміни в міжнародному торгівельному співробітництві, спровоковані коронавірусом, та можливі ризики. Пропонуються заходи, спрямовані на стабілізацію зовнішньоекономічної торгівельної політики України після виходу з карантинного режиму.

Ключові слова: державна митна політика, митні режими, режим імпорту, режим експорту, карантин, економічна криза.

\section{Summary}

Yakovenko Ye.O., Smirnova V.S. Ukraine's foreign trade policy during the introduction of quarantine restrictions. - Article.

The article examines the foreign trade policy of Ukraine; the analysis of customs regulations of Ukraine, the current state of import and export in the mode of quarantine restrictions. The foreign trade policy of the state is a goal-directed activity for the policy making of internal and foreign policy of the state, through the use of public administration mechanisms which are aimed at effective cooperation in the international economics with the observance of interest of national economic and security of citizens. State customs policy is a system of principles and activities responsible for protection of customs interests and security of custom policy of Ukraine, regulation of foreign trade, protection of the internal market, economic development of Ukraine and its integration into the world economy. The article describes customs regulations and conducts analysis of the regimes: import and export. The statistical indicators of imports and exports for January-February 2020 were studied and compared with the indicators of the previous year, as a result of which the reduction of imports of goods by 265.1 million dollars was revealed. $(3.0 \%)$. The analysis of the dynamics of imports of goods among the regions of Ukraine, was found that the largest negative contribution to the dynamics of imports of goods for 2 months of 2020 is observed in Kiev (-1.9\%). It is established that the largest partner countries in the import of goods to Ukraine are: the European Union (42.1\%), China (15.7\%), the Russian Federation (9.5\%), the United States (6\%), Belarus (5, 4\%), Turkey (4.4\%), Japan (1.8\%), India (1.7\%), Switzerland $(1.5 \%)$ and others. The impact of the implementation of quarantine measures on the economy of Ukraine, including the closure of agricultural markets by May 11, 2020, is highlighted. It is proved that by supporting foreign producers and pursuing foreign economic trade policy, Ukraine loses a quality internal market, in addition, having problems in the foreign market. As an example, the article describes the import of potatoes, apples and milk. The situation on the internal and foreign trade markets of Ukraine, changes in international trade cooperation fuelled by by the coronavirus and possible risks are described. Measures aimed at stabilizing Ukraine's foreign trade policy after exit quarantine regime are proposed.

Key words: state customs policy, customs regulations, import regime, export regime, quarantine, economic crisis. 